\title{
International Students' Attitudes towards Malaysian English Ethnolects
}

\author{
Shadi Khojastehrad ${ }^{1}$, Shameem Rafik-Galea ${ }^{1} \&$ Ain Nadzimah Abdullah ${ }^{1}$ \\ ${ }^{1}$ Department of English, Faculty of Modern Languages and Communication, Universiti Putra Malaysia \\ Correspondence: Shameem Rafik-Galea, Department of English, Faculty of Modern Languages and \\ Communication, Universiti Putra Malaysia, 43400 Serdang, Selangor, Malaysia. Tel: 60-389-468-682. E-mail: \\ shameemgalea@gmail.com
}

Received: July 24, 2015 Accepted: September 2, 2015 Online Published: September 5, 2015

doi:10.5539/elt.v8n10p7 URL: http://dx.doi.org/10.5539/elt.v8n10p7

\begin{abstract}
Language attitudes are learned and formed in our social environment through hearing others referring to certain groups or people's languages and cultures, and also by exposure to particular varieties spoken in the context. This might lead to stereotyping English and its native speakers (McKenzie, 2008). In this sense, it is pedagogically significant to uncover learners' language attitudes towards a target language in order to prevent negative impression towards that certain variety and consequently inevitable communication failure with the members of that particular speech community. The present study explores the attitudes of international students living in Malaysia towards Malaysian English. The main objective was to examine the respondents' attitudes towards the Mesolectal variety of Malaysian English spoken by the three main ethnic groups: Malay, Chinese-Malaysian, and Indian-Malaysian. A matched-guise questionnaire was used to elicit information from the students and obtain their responses towards six samples of Malaysian English accents from both male and female speakers. International students from selected Malaysian universities were asked to listen to the recorded speech samples and were then asked to rate the speakers using 15 bipolar adjectives on a Likert scale which were split into two sections of speaker's style of English speaking and social attractiveness, and finally they were asked to guess the ethnicity of the speakers. The findings show that there is a positive linear relationship between attitude towards the Malaysian English variety spoken by each ethnic group, and the intelligibility of that certain variation, which directly affects the listeners' evaluation of the speaker's social attractiveness too.
\end{abstract}

Keywords: attitude, Malaysian English, international students, ethnolects, verbal-guise test

\section{Introduction}

New Englishes have been basically created and developed in countries which were once controlled or largely influenced by the US and the UK like Cameroon English, Carribbean English, Indian English, and Singaporean English (Kachru, 1992). Although New Englishes have increasingly emerged, the Standard English varieties, like the British English and American English, are still considered to be the only acceptable forms of English in many countries. Standard English represents a variety which is mainly characterized by its commonly known prestigious and intelligible vocabulary, grammar and orthography (Crystal, 1995). It is identified as a particular dialect of English, which is not localized and does not have significant variation, and commonly known as the appropriate educational target in teaching English (Stevens, 1985).

\subsection{Attitudinal Study of Non-Native Varieties of English}

The widespread use of English around the word has brought along various language attitudes towards different varieties spoken. These attitudes range from strong rejection to full acceptance and indifferent tolerance of varieties of the language. Speakers as well as linguists have expressed different and often contradictory feelings about the language, its regional (i.e. non-native) speakers' accents and the choice of words, supposed falling standards or degeneration of the language, and the emergence of regional, national and indigenized varieties which are tantamount to ownership of the language by those who are historically foreign to it. Because these Englishes were conceived as mistakes in acquisition or bad English, they were often rejected, sometimes subtly 
and sometimes even violently (Anchimble, 2014).

However, most of the negative attitudes are not based on the quality of the language but rather on attitudinal prejudices and stereotypes not only on the regions but also on the speakers of English from these regions. As an example of these negative attitudes, Ramato (quoted in Dako 2001, p. 46), declares, "People make the excuse that there is Ghanaian English. There is nothing like Ghanaian English. There is English and then the Ghanaian accent but it shouldn't stop us speaking and writing good English." Still in Ghana, Gyasi (1990: p. 24) laments, "English in Ghana is very ill. The cancerous tumors are countless". In Nigeria, Oji (quoted in Jibril 1987, p. 46), declares that "the death-knell of Nigerian English should be sounded 'loud and clear' as it has never existed, does not exist now, and will never see the light of day. The picture gets even more murky as Gyasi (1990: p. 24) refers to possible Ghanaianisms as 'cancer': "The cancer has spread too far and is to be found everywhere: in the English of teachers, journalists, other professionals, ordinary men and women, and students from the secondary school to the university."

Not only negative attitudes have been registered but also positive ones. Speakers have also shown pride in the varieties of English they speak. Others, due to various forms of attitudinal filtration, have remained faithful to their local accents.

For instance, "Only very few Nigerians or Ghanaians would like to surrender their African personality and speak the prestigious English RP" (Yankson, 1989: p. 149).

Similarly, those Ghanaians whose English "strives too obviously to approximate to RP [are] frowned upon as distasteful and pedantic" (Sey 1973, p. 1), and in Cameroon, "Cameroonians who insist on sounding like Britons are ridiculed rather than admired" (Mbangwana, 1987: p. 423, cited in Anchimble, 2014).

\subsection{Previous Lingua-Attitudinal Studies}

Empirical research in the area of language attitudes usually takes into account at least two areas of evaluation. First, there are evaluations in terms of competence, or perceived traits relating to "intelligence" and "self-confidence," among others. In this dimension, speakers of native Englishes are identified with "significantly higher" ratings than the speakers from other groups, such as the case in McKenzie's (2006) dissertation that showed the speaker of Mid-West United States English ranked first, and the speaker of a heavily-accented Japanese English ranked last among six speakers (p. 142). Second, there is an affective side of speaker evaluation, which considers the speaker's social attractiveness, desirability and integrity, and looks at personality traits such as "friendliness" and "warmth" (Birch \& McPhail, 1997: p. 5).

In a study by Scales et al. (2006), it was found out that the accent which is easily intelligible is also the preferred accent. Their study revolved around the accent perceptions of 37 English language learners and 10 American undergraduate students. The findings showed that the British speaker was perceived as the most educated by some students whilst a portion of the students did not like the British speaker, stating, "She sounded like a school teacher". British-accented English is indexed as projecting a speaker as a highly educated individual while Asian-accented English is deemed to be difficult to comprehend. Although, it must be noted that speaking with a certain accent does not indicate one's intelligence (Mahmud \& Ching, 2012).

Similarly, Rajadurai (2007) also made similar remarks in her paper by rebuking some of the common myths about nonnative speech being less intelligible than native speech, which implies that native speakers are not necessarily better understood than their non-native counterparts. The one aspect that is prevalent in Scales et al (2006) is the fact that there is an almost perfect correlation between an ideal accent and one which is easiest to comprehend.

Melander's (2003) study, for example, showed how Swedish listeners had evaluated bilingual speakers using Swedish and English guises. The study demonstrated the Swedish guises are favored on personality traits like self-confidence, sense of humor, and extroversion. Meanwhile, another speaker who spoke in English was judged more positively on all traits related to competence. The positive evaluations stopped when the same speaker's sense of humor was in question (Castro \& Roh, 2013).

Following Lambert et al.'s (1960) groundbreaking research on language attitudes, research has provided ample evidence that speakers with non-standard accents tend to be negatively evaluated, and these evaluations tend to translate into differential treatment of these speakers and lowered expectations of their potential performance (Riches \& Foddy, 1989). 
The scant research on university students' acceptance of non-native English-speaking academics similarly indicates that instructors' ethnicity, manifested by a foreign accent as well as by non-linguistic factors such as Asian facial features (Rubin, 1992) can negatively affect teacher ratings and listening comprehension. A recent incident at a leading Australian university provides poignant empirical support that these claims still apply. As reported by Murray (2008) in the Brisbane daily, The Courier Mail, a "prestigious law school had to sideline a newly appointed Chinese academic because of poor English speaking skills".

However, as Lindemann (2002: p. 419) convincingly argued, 'the claim that a given Non-Native Speakers (NNS) is difficult to understand often rests on the assumption that it is solely the speaker's responsibility to get her point across and disregards the major role listeners play in conversations. Her research shows that, at least in some cases, miscommunication between interactants may be attributed to negative attitudes from native speakers rather than to linguistic incompetence of non-native speakers. A similar conclusion is reached by Lippi-Green (1994: p. 166), who argues that listeners' goodwill plays a crucial role in communication. In her view, communicative failure can often times be attributed to prejudice in listeners who cannot hear what a person has to say, because accent, as a mirror of social identity and a litmus test for exclusion, is more important (Eisenchlas \& Tsurutani, 2011).

For learners of English as a second language, features of pronunciation from their mother tongue can be discerned in their use of English. For example, Zuraida (2000) found that Malay vowels influenced the way the respondents pronounced English vowels. Thus, it is most likely that language learners will struggle to achieve their accent goal if they start learning English later in life and will continually feel frustrated at never obtaining a native accent.

\section{Method}

\subsection{Research Design}

The researcher adopted a mixed method(quantitative-qualitative) research design to investigate the international students' attitude towards Malaysian English spoken by the three main ethnic groups in Malaysia namely Malay, Chinese Malaysian, and Indian Malaysian by a verbal guise test which asked the respondents to evaluate the speakers' English speech recordings by marking a semantic differential test. At the end of the test, the respondents were asked to explain any further ideas, memories, or experiences regarding their attitude towards Malaysian English.

\subsection{Research Setting}

One of the aims of the study was to explore international students' attitude towards Malaysian English through a verbal-guised test. The test was administered at three universities in Kuala Lumpur where the medium of instruction is English.

The participants were asked to listen to 6 speech samples representing three main ethnic groups in Malaysia, namely Malay, Chinese-Malaysian, and Indian-Malaysian for the male and female groups. The recordings were made from the English speech of 1 male and 1 female Malay, 1 male and 1 female Chinese Malaysian, and 1 male and 1 female Indian Malaysian who were selected among a pool of 30 Malaysian graduate students based on a Malaysian English marker check list judged by a panel of experts in phonology. They were given neutral recordings of a map-reading task in order to maintain the speakers' speech content neutrality to prevent judgment based on what was said, and the length of the recordings were kept alike between 40-45 seconds.

\subsection{Sampling Procedure}

Purposive sampling procedure was used to invite international students to participate in the survey. Three focus group discussions were conducted to triangulate the quantitative data obtained from the questionnaire. Participants were invited from the sampling pool of the quantitative phase of the study. The participants were screened based on the following criteria: nationality, university program, and employment. The rationale for determining these elements as screening factors is as follows:

- University Program: The respondents were screened to check if they were still pursuing English programs, they were proficient enough to be able to communicate in English easily and make fair judgement about communication effectiveness with the other communities.

- Employment: The respondents were screened to check if they were working in Malaysia, because the employed participants would have socialized with the locals so often that they would not feel any special 
difficulty to communicate effectively with the locals. Thus the data would lose validity as confounding variables were not controlled.

- Nationality: The respondents were screened to be from diverse nationalities excluding countries where they could also speak the Malay language like Indonesians whose mother tongue share a lot of common linguistic features with Malay. Thus, they did not need to speak English with the locals, except in a few cases when they had to.

\subsection{Participants}

The participants were from diverse nationalities, and were involved in different undergraduate, graduate and postgraduate programs at the three universities. They were all required to obtain an IELTS academic score of not less than 6 to begin university courses. A total of 372 International students participated in this study. The demographics of the respondents are presented in Table.1.

Table 1. Demographics of the respondents

\begin{tabular}{|c|c|c|}
\hline Item & Frequency & Percentage \\
\hline \multicolumn{3}{|l|}{ Gender } \\
\hline Male & 291 & 78.2 \\
\hline Female & 81 & 21.8 \\
\hline \multicolumn{3}{|l|}{ English Language Background } \\
\hline ESL & 82 & 22.0 \\
\hline EFL & 290 & 78 \\
\hline \multicolumn{3}{|l|}{ Age } \\
\hline Less than 20 & 17 & 4.6 \\
\hline 20-30 years old & 195 & 52.4 \\
\hline $31-40$ years old & 135 & 36.3 \\
\hline $41-50$ years old & 24 & 6.5 \\
\hline \multicolumn{3}{|l|}{ Educational Level } \\
\hline Bachelor & 91 & 24.5 \\
\hline Master & 169 & 45.4 \\
\hline $\mathrm{PhD}$ & 103 & 27.7 \\
\hline Post.Doc & 2 & .5 \\
\hline \multicolumn{3}{|l|}{ Field of Study } \\
\hline Linguistics & 101 & 27.2 \\
\hline Non-Linguistics & 271 & 72.8 \\
\hline \multicolumn{3}{|l|}{ Length of Stay in Malaysia } \\
\hline Less than a year & 165 & 44.4 \\
\hline $1-2$ years & 110 & 29.6 \\
\hline $3-4$ years & 44 & 11.8 \\
\hline $4-5$ years & 23 & 6.2 \\
\hline Over 5 years & 29 & 7.8 \\
\hline
\end{tabular}

\subsection{Instrument}

The instrument used for this part of the study was a verbal guise test. The verbal guise test examined the 
respondents' attitude towards the three main ethnolects of Malaysian English: Malay, Chinese Malaysian, and Indian Malaysian's English speech, through an indirect approach. The indirect approach helped the researcher to conceal the purpose of the study from the participants to be able to enhance the research view beyond the participants' conscious awareness. The traits used in the semantic differential scale of the instrument were adapted from Mc Kenzie (2006). These traits are for the respondents' attitude towards the speakers' spoken English which are as follows: unpleasant/pleasant, ordinary/romantic, cold/warm, incorrect/correct, difficult to understand/easy to understand, unclear/clear, funny/not funny, not fluent/ fluent, and their attitude towards the speakers' social attractiveness with the following bipolar adjectives: uneducated/educated, low class/high class, unpleasant/pleasant, bossy/submissive, unconfident/confident, not intelligent/intelligent, not modest/modest.

The researchers also included additional adjectives derived from a focus group discussion held earlier. These adjectives were the most concurrent adjectives describing the participants' impressions of Malaysian English. Eight adjectives were used to evaluate the speakers' English competence and seven adjectives to evaluate their social attractiveness. The selected adjectives were positioned randomly, and the scale started with the most desirable features on the right and the most negative on the left. In this way, the lowest marks were assigned to the most negative adjectives and the highest marks were assigned to the most positive adjectives. The Scale is illustrated below:

\section{A. Speaker \# 4}

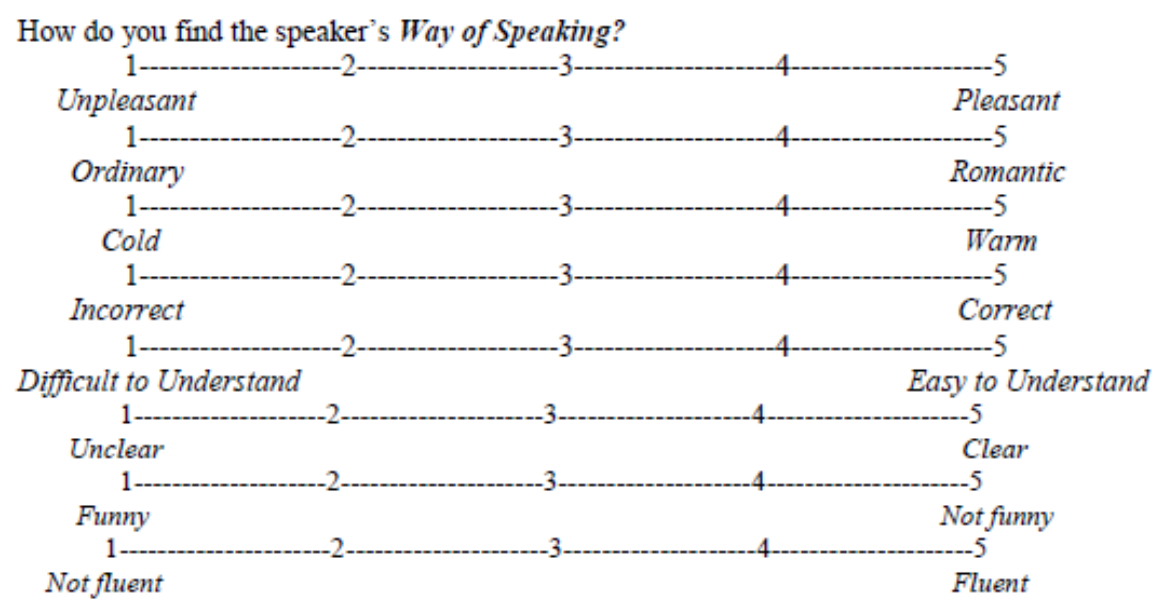

\subsection{Data Analysis}

The quantitative data from the verbal guise test was analyzed by means of SPSS.18 analytical software. A number of statistical analysis techniques were used to explore the respondents' attitudes towards the three main ethnolects of Malaysian English (ME). The main statistical tests used were Descriptive statistics, One-Way ANOVA, and Post-hoc test, and the qualitative data was analyzed by the qualitative data analysis software NVivo.8. The findings of the analysis are presented in the following section.

\section{Findings}

\subsection{Speakers' English Language Competency}

Descriptive statistics was used to calculate the mean score of each single feature of English language competence marked by the participants in order to find out how each speaker was evaluated by the respondents based on the semantic differential test. The findings are presented in Table 2. 
Table 2. Mean scores of attitude towards speakers' English language competence

\begin{tabular}{|c|c|c|c|c|c|c|}
\hline & Speaker1 & Speaker2 & Speaker3 & Speaker4 & Speaker5 & Speaker6 \\
\hline & $\begin{array}{l}\text { Female } \\
\text { Chinese } \\
\text { Malaysian }\end{array}$ & Male Malay & $\begin{array}{l}\text { Male Chinese } \\
\text { Malaysian }\end{array}$ & $\begin{array}{l}\text { Female } \\
\text { Indian } \\
\text { Malaysian }\end{array}$ & $\begin{array}{l}\text { Male Indian } \\
\text { Malaysian }\end{array}$ & $\begin{array}{l}\text { Female } \\
\text { Malay }\end{array}$ \\
\hline $\mathrm{A} 1$ & 2.92 & 2.80 & 2.74 & 3.10 & 3.30 & 2.99 \\
\hline A2 & 2.57 & 2.78 & 2.54 & 2.87 & 2.88 & 2.79 \\
\hline A3 & 2.64 & 2.79 & 2.67 & 2.97 & 2.98 & 2.91 \\
\hline A4 & 2.81 & 2.93 & 2.80 & 3.20 & 3.34 & 3.02 \\
\hline A5 & 2.79 & 2.89 & 2.85 & 3.13 & 3.43 & 3.14 \\
\hline A6 & 2.68 & 3.06 & 2.82 & 3.09 & 3.55 & 3.20 \\
\hline A7 & 3.00 & 2.84 & 3.06 & 3.11 & 3.48 & 2.98 \\
\hline A8 & 2.76 & 2.67 & 2.81 & 3.00 & 3.29 & 3.04 \\
\hline Total & 2.77 & 2.84 & 2.78 & 3.05 & 3.28 & 3.00 \\
\hline
\end{tabular}

Table 3. Definition of codes

\begin{tabular}{ll}
\hline Codes & The adjectives \\
\hline A1 & Unpleasant/Pleasant \\
A2 & Ordinary/Romantic \\
A3 & Cold/Warm \\
A4 & Incorrect/Correct \\
A5 & Difficult to understand/Easy to understand \\
A6 & Unclear/Clear \\
A7 & Funny/Not funny \\
A8 & Not fluent/Fluent \\
\hline
\end{tabular}

Based on the results, the participating international students allotted the first speaker - a female Chinese Malaysian - the lowest mark in terms of perceived English language competence. In contrast, the male and female Indian Malaysian speakers were evaluated as the two most competent English speakers with the mean scores of 3.28 and 3.05 respectively.

The statistics presented in Table 2 for evaluating the speakers' English language competence as perceived by the participants is illustrated in Figure 1 as follows. 


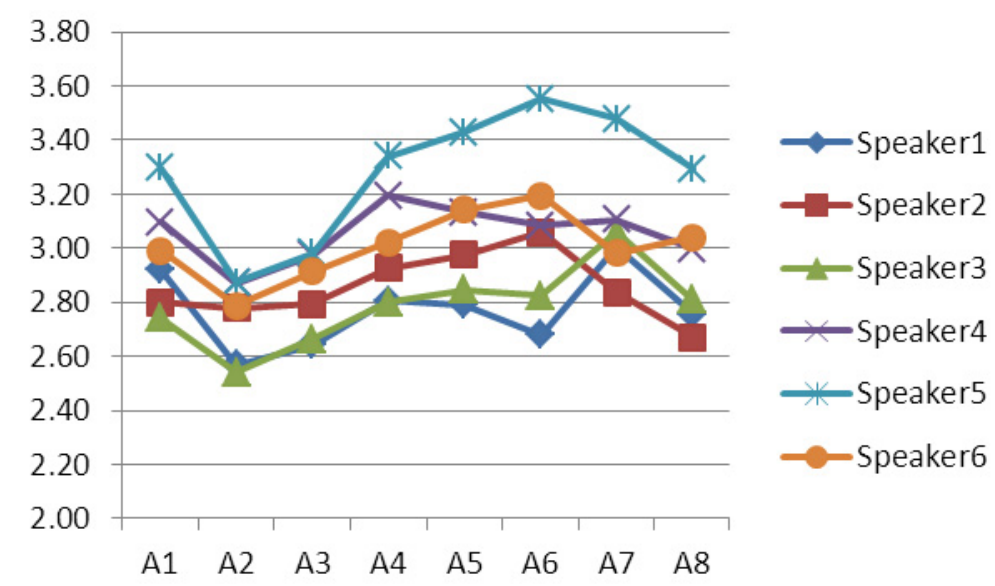

Figure 1. Attitude towards speakers' English competence

As defined in Table 3, A1-A8 stand for the adjectives the respondents marked based on their attitude towards the Speakers' Spoken English, and Speaker.1 refers to Female Chinese Malaysian, Speaker.2: Male Malay, Speaker.3: Male Chinese Malaysian, Speaker.4: Female Indian Malaysian Speaker.5: Male Indian Malaysian, and Speaker.6: Female Malay.

As shown in Figure 1, speaker 3 - a Chinese Malaysian male - received the lowest mark in A1, which represents unpleasant/pleasant and A2 for Ordinary/Romantic way of speaking English. This indicates that the respondents found his way of speaking English the most unpleasant and ordinary among all. According to the figure, the Chinese Malaysian female was ranked lowest for the third feature (Cold/Warm English speaking style), which signifies that the Chinese Malaysian female was perceived as the coldest sounding in English by the majority of respondents. Similar results were found for A4, A5, A6, representing Incorrect/Correct, Difficult to understand/Easy to understand, and Unclear/Clear speaking, where the respondents ranked the Chinese Malaysian woman the lowest. However, for A4 (Incorrect/Correct), the Chinese Malaysian male speaker was ranked lower than the Chinese female by 1 point. However, comparing the mean scores calculated for A7 and A8 shows that the second speaker, a Malay male received the lowest score for sounding Funny/Not funny, and Not fluent/Fluent in English. In contrast, the fifth speaker, who is an Indian Malaysian male, was perceived as the most competent English speaker with the highest mark in all features listed in the table.

In order to test whether the differences between the 6 speakers' scores on the speaker's competence are significant, a one-way ANOVA statistical test of differences was used.

Based on the findings shown in Table 4, there is a significant difference between the 6 speakers' English competence ratings by the international students by showing p-values of less than $0.05(.000<.05)$. 
Table 4. Results of anova for the speaker's English competence

\begin{tabular}{|c|c|c|c|c|c|c|}
\hline \multicolumn{7}{|c|}{ ANOVA } \\
\hline & & Sum of Squares & $\mathrm{df}$ & Mean Square & $\mathrm{F}$ & Sig. \\
\hline \multirow[t]{3}{*}{ A. 1} & Between Groups & 71.737 & 5 & 14.347 & 12.863 & .000 \\
\hline & Within Groups & 2482.957 & 2226 & 1.115 & & \\
\hline & Total & 2554.694 & 2231 & & & \\
\hline \multirow[t]{3}{*}{ A. 2} & Between Groups & 34.841 & 5 & 6.968 & 7.454 & .000 \\
\hline & Within Groups & 2081.030 & 2226 & .935 & & \\
\hline & Total & 2115.871 & 2231 & & & \\
\hline \multirow[t]{3}{*}{ A. 3} & Between Groups & 37.192 & 5 & 7.438 & 7.454 & .000 \\
\hline & Within Groups & 2221.387 & 2226 & .998 & & \\
\hline & Total & 2258.579 & 2231 & & & \\
\hline \multirow[t]{3}{*}{ A. 4} & Between Groups & 78.836 & 5 & 15.767 & 16.000 & .000 \\
\hline & Within Groups & 2193.616 & 2226 & .985 & & \\
\hline & Total & 2272.451 & 2231 & & & \\
\hline \multirow[t]{3}{*}{ A. 5} & Between Groups & 88.756 & 5 & 17.751 & 15.849 & .000 \\
\hline & Within Groups & 2493.215 & 2226 & 1.120 & & \\
\hline & Total & 2581.971 & 2231 & & & \\
\hline \multirow[t]{3}{*}{ A. 6} & Between Groups & 157.858 & 5 & 31.572 & 26.928 & .000 \\
\hline & Within Groups & 2609.855 & 2226 & 1.172 & & \\
\hline & Total & 2767.713 & 2231 & & & \\
\hline \multirow[t]{3}{*}{ A. 7} & Between Groups & 82.333 & 5 & 16.467 & 13.451 & .000 \\
\hline & Within Groups & 2725.022 & 2226 & 1.224 & & \\
\hline & Total & 2807.355 & 2231 & & & \\
\hline \multirow[t]{3}{*}{ A. 8} & Between Groups & 92.154 & 5 & 18.431 & 14.970 & .000 \\
\hline & Within Groups & 2740.661 & 2226 & 1.231 & & \\
\hline & Total & 2832.815 & 2231 & & & \\
\hline
\end{tabular}

After finding significant differences between the respondents' perceptions of the 6 speakers' English language competence, a Bonferroni post-hoc test was carried out in order to identify the exact areas of difference and determine which features showed the highest and lowest differences among the six Malaysian speakers of English for each single feature as shown in the appendix.

\subsection{Speakers' Social Attractiveness}

This section presents the results of the descriptive statistical analysis of the respondents' attitude towards the speakers' social attractiveness. The results are presented in Table 5. 
Table 5. Mean scores of attitude towards the speakers' social attractiveness

\begin{tabular}{lllllll}
\hline & $\begin{array}{l}\text { Speaker1 } \\
\text { Female } \\
\text { Malaysian } \\
\text { Chinese }\end{array}$ & Speaker2 & $\begin{array}{l}\text { Male Malay } \\
\text { Male } \\
\text { Malaysian } \\
\text { Chinese }\end{array}$ & $\begin{array}{l}\text { Speaker4 } \\
\text { Female } \\
\text { Malaysian } \\
\text { Indian }\end{array}$ & $\begin{array}{l}\text { Speaker5 } \\
\text { Male } \\
\text { Malaysian } \\
\text { Indian }\end{array}$ & $\begin{array}{l}\text { Female } \\
\text { Malay }\end{array}$ \\
\hline B1 & 3.09 & 2.81 & 3.09 & 3.2 & 3.57 & 3.15 \\
B2 & 2.8 & 2.71 & 2.99 & 3.02 & 3.4 & 2.92 \\
B3 & 2.97 & 2.98 & 2.85 & 3.16 & 3.31 & 3.03 \\
B4 & 3.09 & 3.03 & 2.82 & 3.05 & 3.19 & 3.08 \\
B5 & 2.84 & 2.99 & 3.01 & 3.11 & 3.42 & 3.18 \\
B6 & 2.98 & 2.81 & 2.91 & 3.19 & 3.37 & 3.11 \\
B7 & 3.14 & 2.96 & 2.98 & 3.22 & 3.32 & 3.13 \\
Total & 2.98 & 2.89 & 2.95 & 3.19 & 3.36 & 3.08 \\
\hline
\end{tabular}

The adjectives for the second section of the verbal guised test which asked the respondents to evaluate the speakers' social attractiveness are characterized by B1-B7 with their complete definition codes as shown in Table 6.

Table 6. Definition of codes

\begin{tabular}{ll}
\hline Codes & The Adjectives \\
\hline B1 & Uneducated/Educated \\
B2 & Low class/High class \\
B3 & Unpleasant/Pleasant \\
B4 & Bossy/Submissive \\
B5 & Unconfident/Confident \\
B6 & Not intelligent/Intelligent \\
B7 & Not modest/Modest \\
\hline
\end{tabular}

As seen in Table 5 the highest mean score of social attractiveness was allotted to the Malaysian Indian male. This finding is the same as that obtained in the previous section regarding the respondents' attitude towards the speakers' English language competence. The results show that the Malaysian Indian female had the second most positive impression on the participants in terms of social attractiveness. On the other hand, the Malay male speaker was perceived the least socially attractive speaker among all, with the lowest total frequency of mean scores given for the underlying features of social attractiveness as listed in Table 6.

A detailed view of the scores given to the speakers for each feature of social attractiveness is presented in the Figure 2 below. 


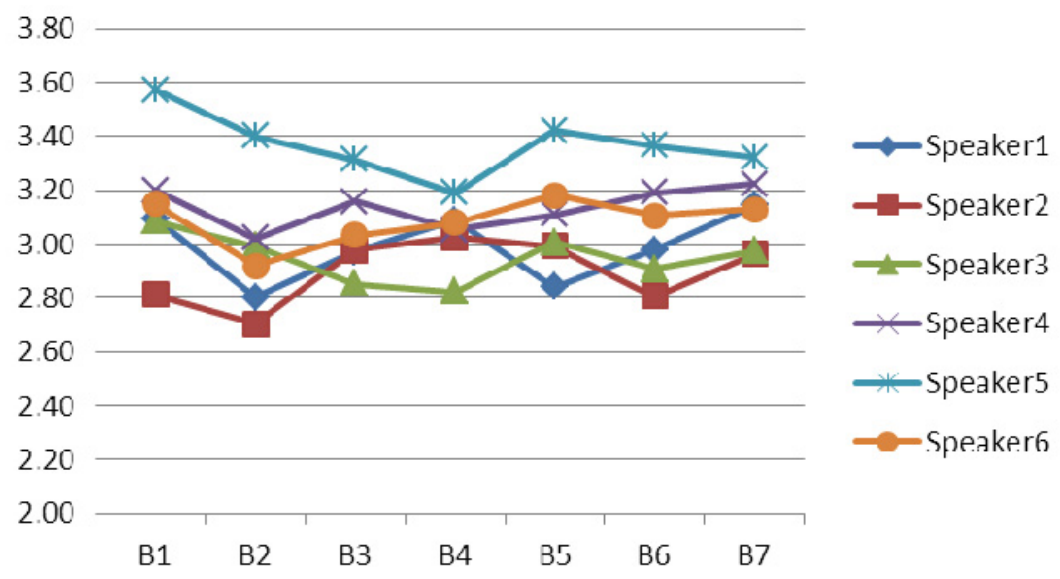

Figure 2. Attitudes towards speakers' social attractiveness

As shown in Figure 2, the lowest score among all features under social attractiveness is noticeable for B2 (Low class/High class), which was assigned to the second speaker (the Malay male); whereas the fifth speaker who is a Malaysian Indian male was perceived to be the most high-class based on the highest mean scores he received for this feature. Considering the other features of social attractiveness, the Malay male speaker received the lowest mark for B1, B2, B6, and B7, which stands for uneducated/educated, Low class/high class, not intelligent/intelligent, not modest/modest. On the other hand, the Malaysian Indian male received the highest mark for all features of social attractiveness; therefore, he was perceived as the most educated, high class, pleasant, submissive, confident, intelligent, and modest. However, the third speaker, who is a Malaysian Chinese male, was ranked the lowest for features B3 and B4, which represent unpleasant/pleasant and bossy/submissive. This implies that the respondents perceived the Malaysian Chinese male as authoritarian and most unpleasant speaker from listening to his English speech.

In order to test whether the differences between the 6 speakers' scores on the speaker's social attractiveness are significant, a one-way ANOVA statistical test of differences was used.

Based on the findings shown in Table 7, there is a significant difference between the 6 speakers' social attractiveness ratings by the international students. The p-values obtained for all in section B were less than $0.05(.000<.05)$. 
Table 7. Results of anova for the speaker's social attractiveness

\begin{tabular}{lllllll}
\hline \multicolumn{5}{c}{ ANOVA } & & \\
\hline & & Sum of Square & Df & Mean Square & F & Sig \\
\hline B.1 & Between Groups & 102.548 & 5 & 20.510 & 20.055 & .000 \\
& Within Groups & 2276.419 & 2226 & 1.023 & & \\
& Total & 2378.968 & 2231 & & & \\
B.2 & Between Groups & 96.083 & 5 & 19.217 & 23.957 & .000 \\
& Within Groups & 1785.562 & 2226 & .802 & & \\
& Total & 1881.645 & 2231 & & & \\
B.3 & Between Groups & 42.814 & 5 & 8.563 & 10.038 & .000 \\
& Within Groups & 1898.863 & 2226 & .853 & & \\
& Total & 1941.677 & 2231 & & & \\
B.4 & Between Groups & 23.975 & 5 & 4.795 & 5.674 & .000 \\
& Within Groups & 1881.315 & 2226 & .845 & & \\
& Total & 1905.290 & 2231 & & & \\
B.5 & Between Groups & 64.472 & 5 & 12.894 & 13.353 & .000 \\
& Within Groups & 2149.492 & 2226 & .966 & & \\
& Total & 2213.964 & 2231 & & & \\
B.6 & Between Groups & 68.448 & 5 & 13.690 & \multirow{2}{*}{14.669} & .000 \\
& Within Groups & 2077.325 & 2226 & .933 & & \\
& Total & 2145.774 & 2231 & & & \\
B.7 & Between Groups & 32.229 & 5 & 6.446 & 7.063 & .000 \\
& Within Groups & 2031.591 & 2226 & .913 & & \\
& Total & 2063.821 & 2231 & & & \\
\hline
\end{tabular}

After identifying significant differences between the respondents' perceptions of the 6 speakers' social attractiveness, a Bonferroni post-hoc test was executed in order to identify the exact areas of difference and determine which features showed the highest and lowest differences among the six Malaysian speakers of English on each single feature as presented in the appendix.

Some of the respondents discussed their attitude towards the main 3 ethnolects in an open space provided to elaborate ideas on Malaysian English spoken by Malays, Malaysian Chinese, and Malaysian Indians' as perceived by the respondents. The findings of the qualitative data is consistent with that of the quantitative findings and is as illustrated below in excerpts 1-6:

\section{Excerpt 1}

"....my problem was the Malaysian accent especially in the Chinese Malaysian. I even had one friend, he was Malaysian Chinese. Seriously I didn't understand whatever he said. I just said OK OK. You're right; because I didn't get used to that skill. I mean that accent." (Iraqi male)

Excerpt 2

"....actually I have the same experience, at the beginning I had a lot of problem with the Malaysian speaking or the Chinese speaking." (Iranian male) 
Excerpt 3

“...I can't understand the Chinese shop girls at all, I can only hear some ambiguous sound and their mouth movements."

(Sudanese female)

Excerpt 4

"...who is can speak English very well only two types or two people , only USA or British and another person exactly cannot speak very well same me same another peoples. I think this is enough."

(Saudi Arabian male)

Excerpt 5

“...pure English... British or American English just inspire students to speak like this not mixing with the language. That's why...because for new peoples when they coming it's gonna be hard." (Yemeni male)

Excerpt 6

\begin{abstract}
"Malaysians speak English wrong, they have very poor English because I'm from English speaking country so I would tend to have more difficulties understanding most of their words and sentences so for us it takes time to get acquaintance with their own style of speaking." (Nigerian male)
\end{abstract}

The discussions by the respondents support the findings obtained from the verbal guise test regarding the respondents' attitude towards English varieties spoken by different ethnic groups in Malaysia. It shows that Malaysian Chinese do not sound understandable to international students, and they were rated as the lowest both in English competence, and social attractiveness accordingly. The findings are consistent with Scales et al.'s (2006), whereby the respondents indicated that it is acceptable to have a non-native accent as long as the listener is able to easily understand the speech, and the flow of the speech is smooth and fluent.

These findings further support one of the axiom of the Schema theory which maintains that:

Axiom 1: The more often a person repeats a schema-based behavior in his or her culture, the more likely it is for the schema to be stored in the person's memory.

As discovered and discussed by the participants, they only developed the schema of native/non-native dichotomy in the mind and were not aware of the diversity of English language varieties worldwide. This occurred because they were constantly instructed to practice standard native varieties, and as a result they came to believe that only these two recognized native varieties of English (British and American English) are acceptable forms and any other deviating versions are not favored or correct.

\title{
4. Conclusion
}

The findings obtained from the verbal guise test in the present study show that the Chinese Malaysian English variety as perceived by most participants affected their attitude towards this particular variety and its speakers. They evaluated it the most negatively for the majority of English language competence features and speakers' social attractiveness. However, the intelligibility of the English spoken by both the Malaysian Indian male and female speakers led to a positive attitude towards their English language competence and social attractiveness.

The results obtained in this study are consistent with Chiba, Matsuura and Yamamoto's (1995), who found that the Japanese university students in their study had the most highly rated accents, for being easily recognized and familiar. Also, Kenzie's study (2006) demonstrated in the matched guise test that the speaker of Mid-West United States English ranked first, and the speaker of heavily-accented Japanese English ranked last among six speakers (p. 142). However, the current results do not comply with those of Edwards (1989), Holmes, Murachver and Bayard(2001) and Kang and Rubin (2009).They showed that English speakers identified as ethnic minority groups were subjected to a higher degree of negative evaluation in terms of intelligence and status than people who speak English associated with the ethnic majority. As it was discovered in this study, the Malay ethnic group, 
which is the majority in Malaysia, was evaluated quite negatively for English proficiency and the second most negatively for social attractiveness. However, the Malaysian Indian ethnic group, which is a minority compared to the Malaysian Malay and Chinese ethnic groups, ranked the highest among these two majority ethnic groups. Thus, it can be suggested that majority and minority ethnic groups cannot be determining factors in contexts where English is not spoken as the first language, because Malaysian Indians whose ancestors were second-language speakers of English sound more intelligible to foreigners than Malaysian Chinese whose ancestors were foreign-language speakers of English. Therefore, the best determining factor in language attitude studies of English varieties as found in the present study is that of the intelligibility and recognisability of a variation to the listeners. The findings clearly showed that the Indian Malaysian male appear to be attributed with all the best features of a competent English speaker by being rated as the most educated, high class, intelligent, and modest speaker among all.

\section{Acknowledgements}

We gratefully acknowledge the support and generosity of the academic coordinators, lecturers, and international students at the public and private universities in Malaysia without which the present study could not have been completed.

\section{References}

Anchimbe, E. A. (2014). Attitudes Towards Cameroon English: A Sociolinguistic Survey Structural and Sociolinguistic Perspectives on Indigenisation (pp. 121-143). Springer. http://dx.doi.org/10.1007/978-94-007-7881-8_7

Birch, D., \& McPhail, J. (2010). The impact of accented speech in international television advertisements. Global Business Languages, 2(1), 9.

Castro, M. C. A., \& Roh, T. R. D. G. (2013). The Effect of Language Attitudes on Learner Preferences: A Study on South Koreans' Perceptions of the Philippine English Accent.

Crystal, D. (1995). The Cambridge Encyclopedia of the English Language. Cambridge: Cambridge University Press.

Dako, K. (2001). Ghanaianisms: Towards a semantic and formal classification. English World-Wide, 22(1), 23-53. http://dx.doi.org/10.1075/eww.22.1.03dak

Eisenchlas, S. A., \& Tsurutani, C. (2011). You sound attractive! Perceptions of accented English in a multi-lingual environment. Australian Review of Applied Linguistics, 34(2), 216.

Gyasi, I. K. (1990). The state of English in Ghana. English Today, 6(3), 24-26. http://dx.doi.org/10.1017/S0266078400004879

Kachru, B. (1992). A Case Study. The Other Tongue: English Across Cultures. In B. B. Kachru (Ed.) (2nd Edition) (pp. 233-252). Urbana, Illinois: University of Illinois Press.

Lambert, W. E., Hodgson, R. C., Gardner, R. C., \& Fillenbaum, Sa. (1960). Evaluational reactions to spoken languages. The Journal of Abnormal and Social Psychology, 60(1), 44. http://dx.doi.org/10.1037/h0044430

Leimgruber, J. R. E. (2013). The trouble with World Englishes. English Today, 29(03), 3-7. http://dx.doi.org/10.1017/S0266078413000242

Lindemann, S. (2005). Who speaks "broken English"? US undergraduates' perceptions of non - native English. $\begin{array}{llll}\text { International Journal of Applied } & \text { Linguistics, } & 15(2), & \text { 187-212. }\end{array}$ http://dx.doi.org/10.1111/j.1473-4192.2005.00087.x

Lippi-Green, R. (1994). Standard language ideology, and discriminatory pretext in the courts. Languag in Society, 23(2), 163-198. http://dx.doi.org/10.1017/S0047404500017826

Mahmud, M. M., \& Ching, W. S. (2012). Attitudes towards accented speech among radio deejays in Malaysia. Academic Research International, 2(3), 520-530.

Melander, L. (2003). Language attitudes: Evaluational reactions to spoken language.

Mbangwana, P. N. (1987). Some characteristics of sound patterns of Cameroon standard English. Multilingua IV (4), 411-424. http://dx.doi.org/10.1515/mult.1987.6.4.411 
McKenzie, R. M. (2007). A quantitative study of the attitudes of Japanese learners towards varieties of English speech: Aspects of the sociolinguistics of English in Japan.

Munro, M. J. (2008). Foreign accent and speech intelligibility. Phonology and second language acquisition, 193-218. http://dx.doi.org/10.1075/sibil.36.10mun

Rajadurai, J. (2007). Intelligibility studies: A consideration of empirical and ideological issues. World Englishes, 26(1), 87-98. http://dx.doi.org/10.1111/j.1467-971X.2007.00490.x

Riches, P., \& Foddy, M. (1989). Ethnic accent as a status cue. Social Psychology Quarterly, 197-206. http://dx.doi.org/10.2307/2786714

Rubin, D. L. (1992). Nonlanguage factors affecting undergraduates' judgments of nonnative English-speaking teaching assistants. Research in Higher Education, 33(4), 511-531. http://dx.doi.org/10.1007/BF00973770

Sey, K. A. (1973). Ghanaian English. London: Macmillan.

Strevens, P. (1977). New Orientations in the teaching of English. London: Oxford University Press.

Yankson, K. E. (1989). Better English through concord for West African students. Uruowulu-Obosi, Nigeria: Pacific Publishers.

Zuraidah, M. D. (2000). "Malay + English -> a Malay variety of English vowels and accent.” In Halimah \& Ng (Eds.), (pp. 35-45).

\section{Copyrights}

Copyright for this article is retained by the author(s), with first publication rights granted to the journal.

This is an open-access article distributed under the terms and conditions of the Creative Commons Attribution license (http://creativecommons.org/licenses/by/3.0/). 